دراسات في آثار الوطن العربي 11

\title{
المدلول الإجتماعى لأيام العرب قبل الإسلام
}

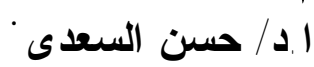

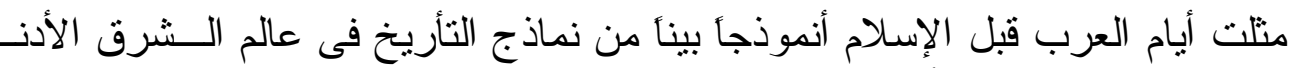

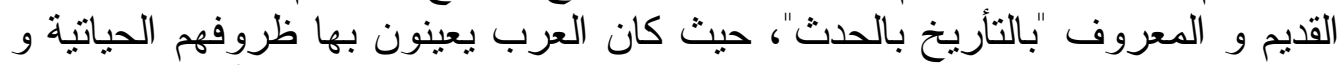

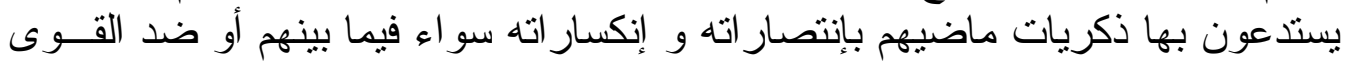

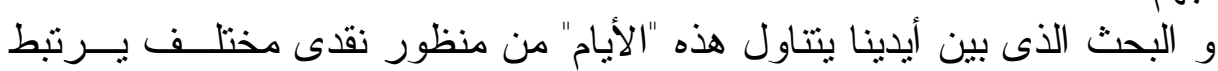

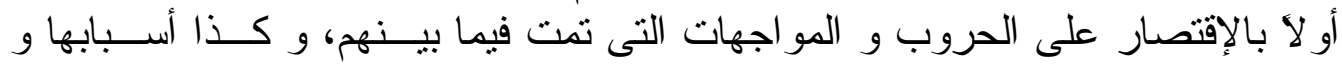

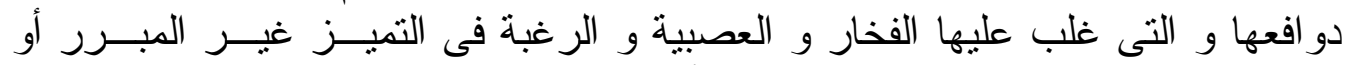

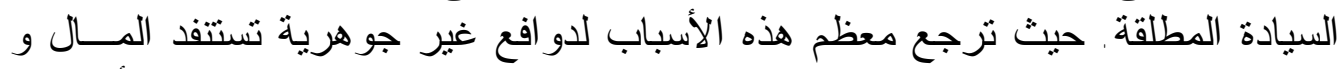

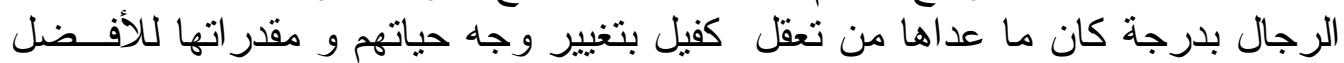

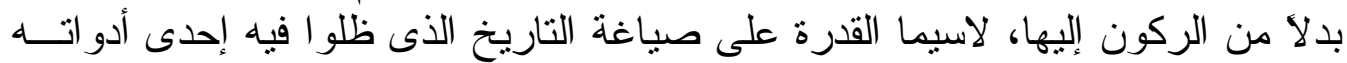

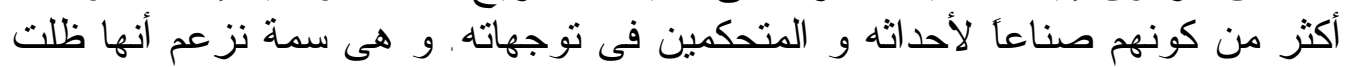

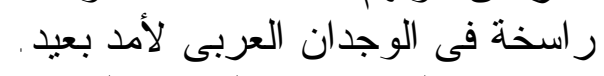
و لقد إقتصر البحث على ثناثة أمثلة رئيسية لتلك الأيام على كثرتها و تباين

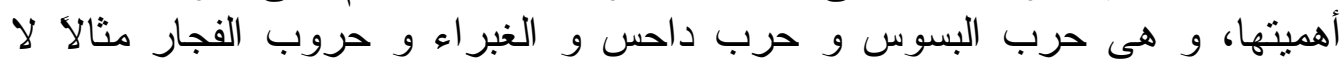

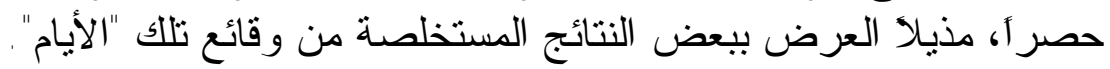

• ألقى ملخص البحث ولم يقام البحث للنشر بكتاب مؤتمر 9 . . بم -كلية الآداب - جامعة الأسكندرية 